\title{
A comparison of reproductive cycles and reproductive output in four southern African mussel species
}

\author{
C. van Erkom Schurink, C. L. Griffiths \\ Marine Biology Research Institute, University of Cape Town, Rondebosch 7700, South Africa
}

\begin{abstract}
The timing and intensity of spawning events in 4 southern African mussel species were deduced from fluctuations in the dry flesh weight of standard-sized individuals, as calculated from monthly length-weight regressions. The sex ratios in 3 of the 4 species (Aulacomya ater, Choromytilus meridionalis and Perna perna) were biased in favour of males, but this was not the case for Mytilus galloprovincialis. The calorific value of females was higher than that of males in all species. A. ater spawned 3 times a year, although these spawning events differed considerably in timing and intensity between years. C. meridionalis and $M$. galloprovincialis generally showed 2 protracted spawning seasons, one each during summer and winter. P. perna from Natal spawned over an extended period from May/June to December, while those from the Cape and Transkei had a well-marked winter spawning, accompanied by either 1 extended, or 2 discrete, spring or summer events. Gamete build-up and release resulted in marked variations in flesh yield. This was greatest in $M$. galloprovincialis, where dry flesh weight can vary 3 -fold between ripe and spawned conditions at a length of $65 \mathrm{~mm}$. Equivalent values for $A$. ater, C. meridionalis and P. perna were 2.3-, 2.8- and 2.2-fold respectively. Total individual reproductive output was greatest in $A$. ater, because of its 3 annual spawnings, followed by $M$. galloprovincialis, $C$ meridionalis and $P$. perna. When extrapolated to a population level, beds of mussels were estimated to release 3.4 to $10.4 \mathrm{~kg}$ wet mass gametes $\mathrm{m}^{-2} \mathrm{yr}^{-1}$ This represents a large energy subsidy to adjacent benthic and pelagic communities.
\end{abstract}

\section{INTRODUCTION}

The reproductive biology of marine mussels has been a topic of research for over $50 \mathrm{yr}$, and the subject has been reviewed several times, notably by Fretter \& Graham (1964), Seed (1976), Sastry (1979), Suchanek (1985) and Griffiths \& Griffiths (1987). A knowledge of the timing and intensity of spawning events is of particular importance to the mussel culture industry, since it can be used to predict subsequent spat settlement. Gamete release also has an immediate and important effect on the market value of the adult stock, since over half the total wet flesh mass can be lost in a single spawning event (see for example Griffiths 1977). In a wider ecological perspective mussel gametes can act as a significant energy subsidy to the pelagic and benthic filter-feeding communities adjacent to the beds. Griffiths (1981a) has, for example, estimated that Choromytilus meridionalis populations can release as much as $19.8 \mathrm{~kg}$ wet mass gametes $\mathrm{m}^{-2} \mathrm{yr}^{-1}$ into the overlying water column, while Kautsky (1982) estimates repro- ductive output by Baltic Mytilus edulis as equivalent to half the total zooplankton production in the area. Since mussels are major space-occupiers, the frequency and intensity of spat settlement also has a profound influence on the communities colonizing both natural rocky shores and man-made structures. These effects include build-up of fouling layers, the displacement or facilitation of other sedentary species and the provision of food for a variety of predatory forms, including man (for review see Suchanek 1985).

The southern African coastline is colonized by 4 abundant mussel species, the distribution patterns and diagnostic features of which are described by van Erkom Schurink \& Griffiths (1990). One of the species, the brown mussel Perna perna, is a warm-water form which extends from Moçambique to the southwestern Cape, but is rare along the Cape west coast, reappearing again in northern Namibia. The remaining forms, the ribbed mussel Aulacomya ater, the black mussel Choromytilus meridionalis and the introduced Mediterranean mussel Mytilus galloprovincialis, achieve 
their maximum biomass along the cooler west coast, although they all penetrate eastwards along the southern Cape coast at reduced densities.

Several earlier studies have addressed the reproductive biology of these species. In the case of Perna perna reproductive cycles of populations from the Durban area (Berry 1978) and from Transkei (Lasiak 1986) have been documented, while some additional information is available on settlement patterns along the southern Cape coast (Crawford \& Bower 1983). Reproductive cycles of Aulacomya ater from the Cape Town area are described by Griffiths (1977) and Griffiths \& King (1979), the latter also providing quantitative estimates of gamete output. In the same area Griffiths (1977, 1981 b) estimated reproductive output in several different populations of Choromytilus meridionalis. No previous studies have examined southern African Mytilus galloprovincialis, although a number of authors have documented their spawning behaviour in the northern hemisphere, as reviewed by Seed (1976).

Our principal objective here is to compare the spawning cycles and reproductive output in southern African populations of these 4 mussel species. To do so we have elected to repeat the measurements for Aulacomya ater and Choromytilus meridionalis, while simultaneously measuring reproductive output for Mytilus galloprovincialis and Perna perna in the same geographical region (in the vicinity of Cape Town). This has been done not only to eliminate methodological differences between the various earlier studies, but also to minimize interannual variations that might be caused by temperature and other environmental conditions (such as food availability), which are well known to effect spawning intensity (see review by Seed 1976). Such variables probably account for at least some of the considerable interannual variations in gonad output noted by Griffiths \& King (1979) and Griffiths (1981b).

In addition to establishing the patterns of spawning over a 2 yr period in this single geographic region, we incorporate other data and speculate as to the geographical and interannual variability in the reproductive cycles of southern African mussel species and estimate interspecific differences in reproductive output. The implications of reproductive activity for the flesh yield of collected mussels as well as for the biotic community as a whole are also considered.

\section{METHODS}

The following analyses are based upon monthly samples of 50 mussels of each species collected during low water of spring tides between January 1987 and December 1988. Samples were structured to incorporate an even size spectrum of individuals over the length range $30 \mathrm{~mm}$ and upwards and were taken from the lower portion of the intertidal range. Aulacomya ater, Choromytilus meridionalis and Mytilus galloprovincialis were collected at Bloubergstrand, in Table Bay, some $20 \mathrm{~km}$ north of Cape Town (the same site used by Griffiths 1977). Perna perna, which is rare at this site, was collected from Diddo Valley in False Bay, some $50 \mathrm{~km}$ to the south (Fig. 1).

In the laboratory, mussels were placed in a wire basket and briefly immersed in rapidly boiling water until the shell valves gaped. After rinsing in cold water the shell length of each individual was recorded, the byssus removed, the sex noted and the flesh transferred to an individually numbered aluminium dish to be dried for $48 \mathrm{~h}$ at $55^{\circ} \mathrm{C}$ and then weighed.

Dry flesh weights were subsequently regressed against shell length for each sample and the predicted weight of a standard $65 \mathrm{~mm}$ individual read from the regression equation. These data were subsequently plotted against time to provide an index of temporal cycles of gonad accumulation and gamete release. This is essentially the same technique for obtaining gonad condition used by authors such as Berry (1978), Griffiths \& King (1979), Bayne \& Worrall (1980) and Kautsky (1982) and has previously been correlated with and shown to provide a realistic reflection of gonad release in Aulacomya ater, Choromytilus meridionalis (Griffiths 1977), and Perna perna (Berry 1978, Lasiak 1986). The uncoupling of shell and tissue growth (see Hilbish 1986) is not the problem here that it is in Europe, where shell growth essentially ceases during winter. South African mussels grow fairly evenly throughout the year.

Calorific values for the flesh of males and females of each species were obtained by burning triplicate samples of each (derived from a pooled sample of 50 individuals of each sex) in a Digital Data Systems CP 500 Calorimeter.

\section{RESULTS AND DISCUSSION}

\section{Sex ratios and calorific values}

The mean ratios of males to females in the 24 monthly samples are depicted in the upper panel of Fig. 2. The sex ratio (percentages) in 3 of the species appears to be markedly skewed in favour of males, the disparity being greatest in Aulacomya ater (66:34 males:females) followed by Perna perna (64:36) and finally Choromytilus meridionalis (60:40). All 3 of these ratios differ significantly from equality (Chi-square tests, $p<0.05$ ). Interestingly this tendency is not exhibited by Mytilus galloprovincialis, where males were slightly outnumbered by females in the ratio of $48: 52$ 
Fig. 1. Southern Africa, showing the locations of sites mentioned in the text

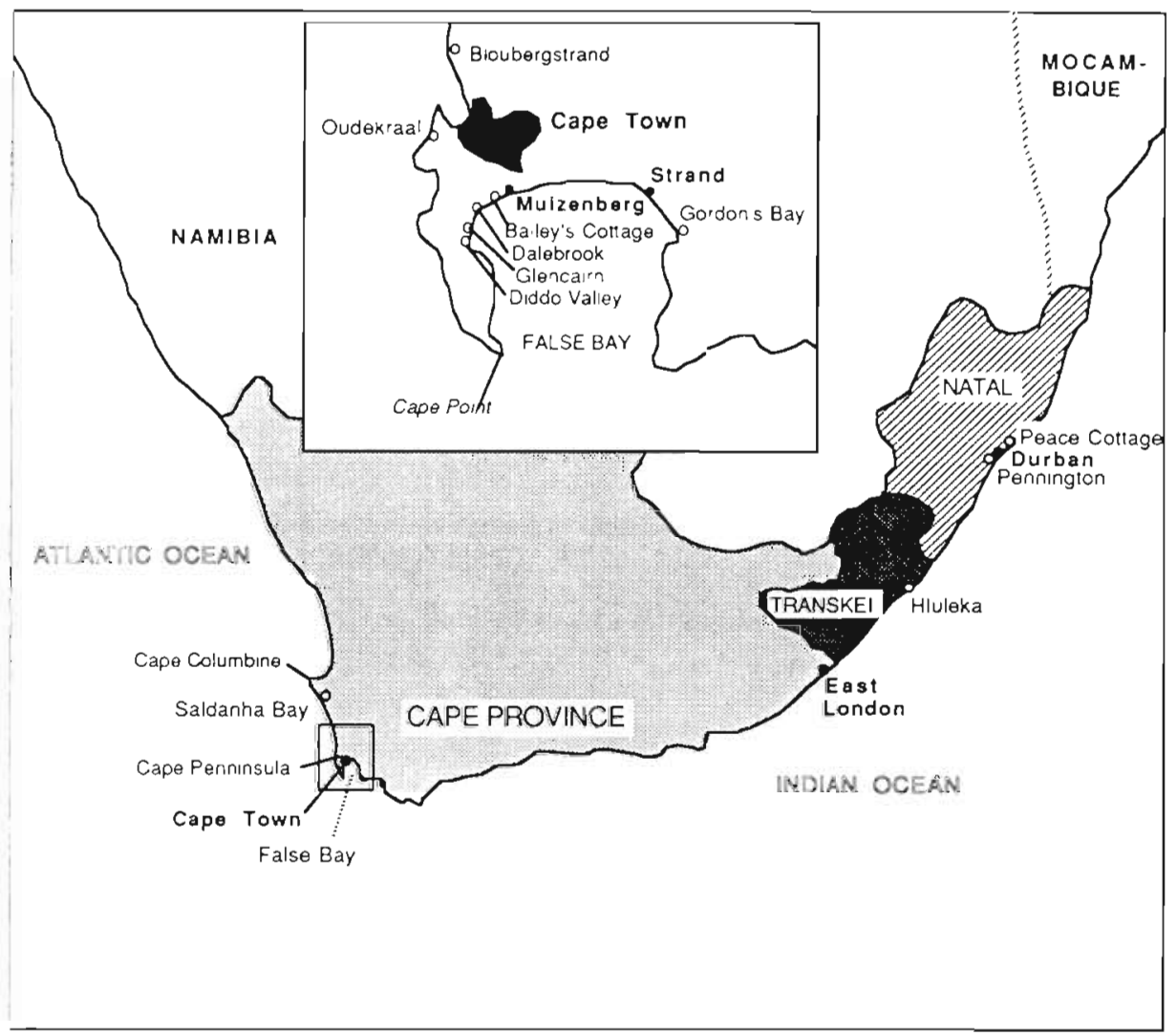

Fig. 2. Sex ratios and comparative calorific values of males and females in 4 southern African mussel species

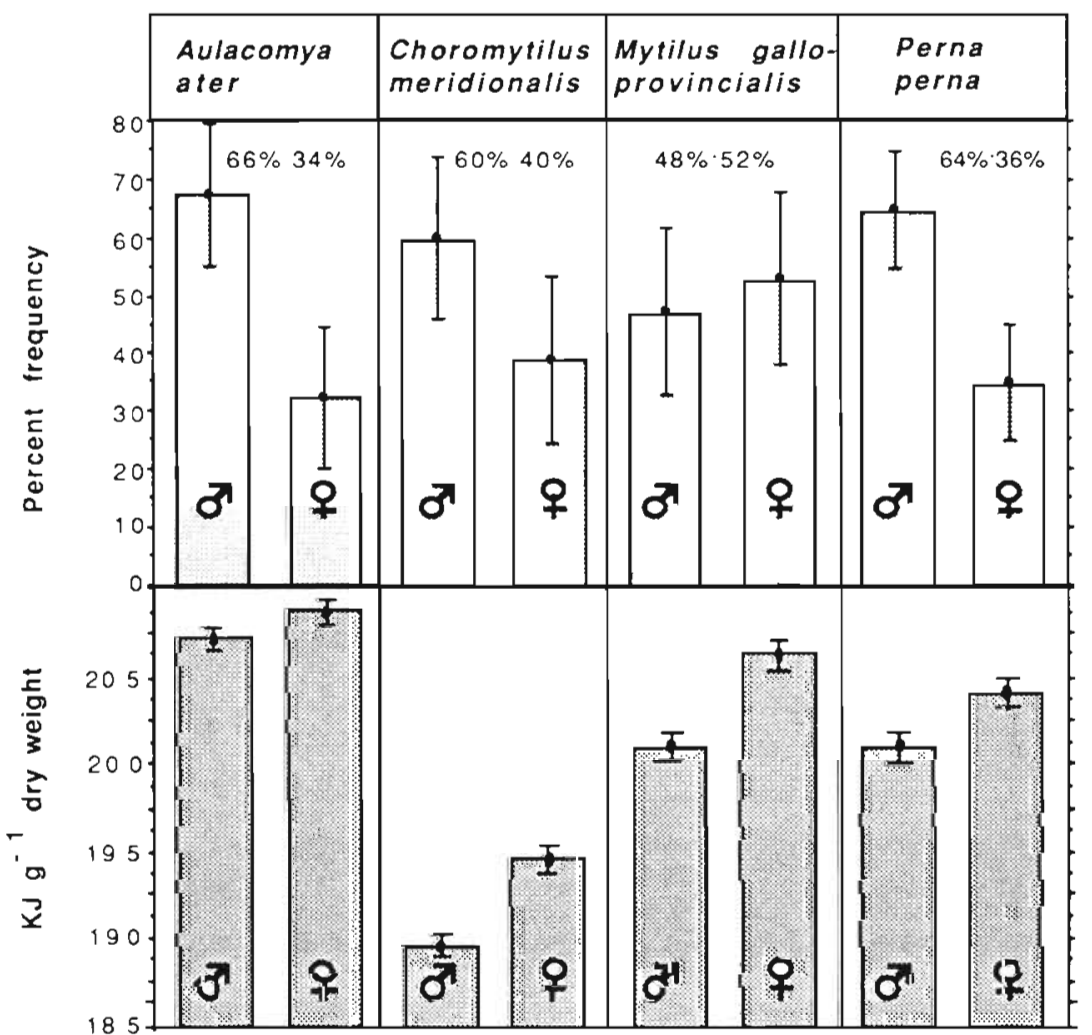


males:females. These proportions do not, however, significantly differ from equality $(p>0.05)$.

Although not all authors give sex ratios for their studies, populations showing similar but less marked biases in sex ratios have been noted in the past. For example, Griffiths (1977) gives a sex ratio of 57:43 males:females for Choromytilus meridionalis and Lasiak (1986) one of 52:48 for Perna perna. Griffiths \& King (1979) did not state sex ratios for their population of Aulacomya ater, but reexamination of their data sheets shows that of 800 specimens sexed males comprised $53 \%$ and females $47 \%$. There are no published records of sex ratios in Mytilus galloprovincialis from southern Africa, but a predominance of females has been recorded in several northern hemisphere populations of the closely related Mytilus edulis (e.g. Chipperfield 1953, Sugiura 1959, Kautsky 1982).

The ecological significance of these biased sex ratios can only be speculated upon. A male mussel produces ca $10^{4}$ times more gametes per unit of reproductive output than a female and both tend to spawn similar amounts by weight (Thompson 1979). Given the presumed rapid dilution factor of sperm in the water column, it is not known whether the number of eggs fertilized is ultimately limited by the rate of egg or of sperm production. In any event this would probably be strongly influenced by such factors as packing density, spawning synchrony and water movement.

Flesh calorific values, shown in the lower panel of Fig. 2, were marginally but significantly higher in females than in males for all 4 species (Student's $t$-test, $p<0.05$ ). This is possibly a result of a high lipid content of the gonad material in the mantle of females, as noted for Mytilus galloprovincialis by Lubet et al. (1986). Mean values were highest in Aulacomya ater at $20.8 \mathrm{~kJ}$ $\mathrm{g}^{-1}$ dry flesh, followed by $M$. galloprovincialis at 20.4 $\mathrm{kJ} \mathrm{g}^{-1}$ and Perna perna at $20.3 \mathrm{~kJ} \mathrm{~g}^{-1}$, while Choromytilus meridionalis flesh had a considerably lower mean calorific value of $19.3 \mathrm{~kJ} \mathrm{~g}^{-1}$. These figures agree closely with the previously published values of $22.1 \mathrm{~kJ}$ $\mathrm{g}^{-1}$ for A. ater (Griffiths \& King 1979), $20.1 \mathrm{~kJ} \mathrm{~g}^{-1}$ for $M$. galloprovincialis (Adachi 1972, Hosomi 1985), $20.3 \mathrm{~kJ}$ $\mathrm{g}^{-1}$ for $P$. perna (Berry 1978) and $19.5 \mathrm{~kJ} \mathrm{~g}^{-1}$ for $C$. meridionalis (Griffiths 1981a). The lower values in $C$. meridionalis may be a function of the frequent absence of interfollicular storage materials in the post-spawning gonad of this species, as discussed by Griffiths (1977).

\section{Annual reproductive cycles}

Seasonal fluctuations in the dry flesh weights of standard $65 \mathrm{~mm}$ shell length individuals of each species are illustrated in Fig. 3. The diagrams apply equally to males and females, since earlier workers

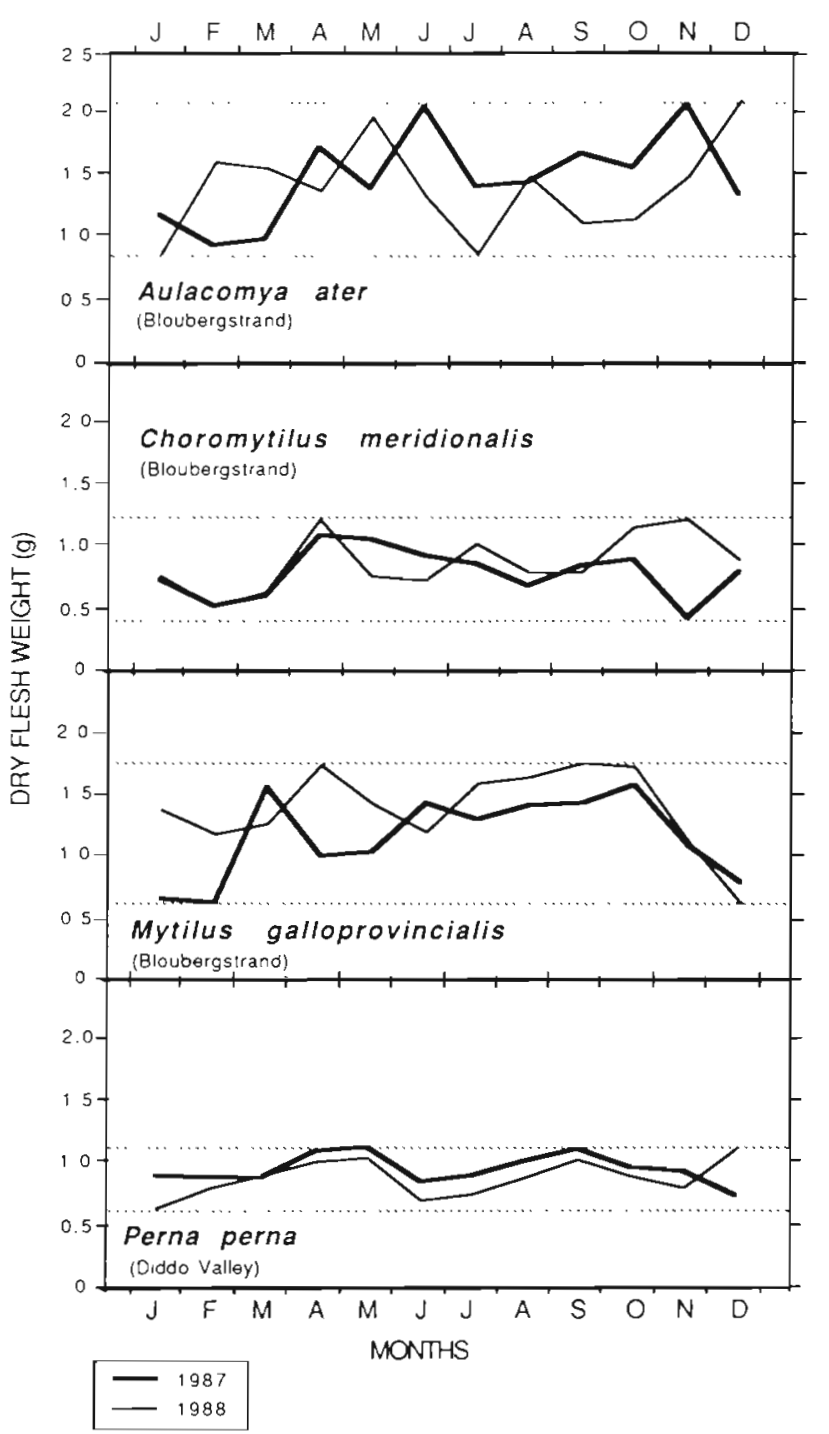

Fig. 3. Seasonal fluctuations in dry flesh weight of standard individuals ( $65 \mathrm{~mm}$ shell length) of each of 4 southern African mussel species over the years 1987-1988

have shown that condition factors of the 2 sexes cannot be distinguished (Griffiths 1977, Griffiths \& King 1979). Spawning events appear on these plots as declines in dry flesh mass, the magnitude of which can be taken as indicative of the quantities of gametes released on each spawning. The relationships between these fluctuations in flesh weight and gamete maturation and release in both Aulacomya ater and Choromytilus meridionalis from the southwestern Cape have previously been demonstrated by Griffiths (1977) using gonad sectioning techniques.

In Aulacomya ater the results in Fig. 3 appear to show 3 spawning bouts in each year, although these differ considerably in timing and intensity between the 2 years of measurement. The remaining species show a 


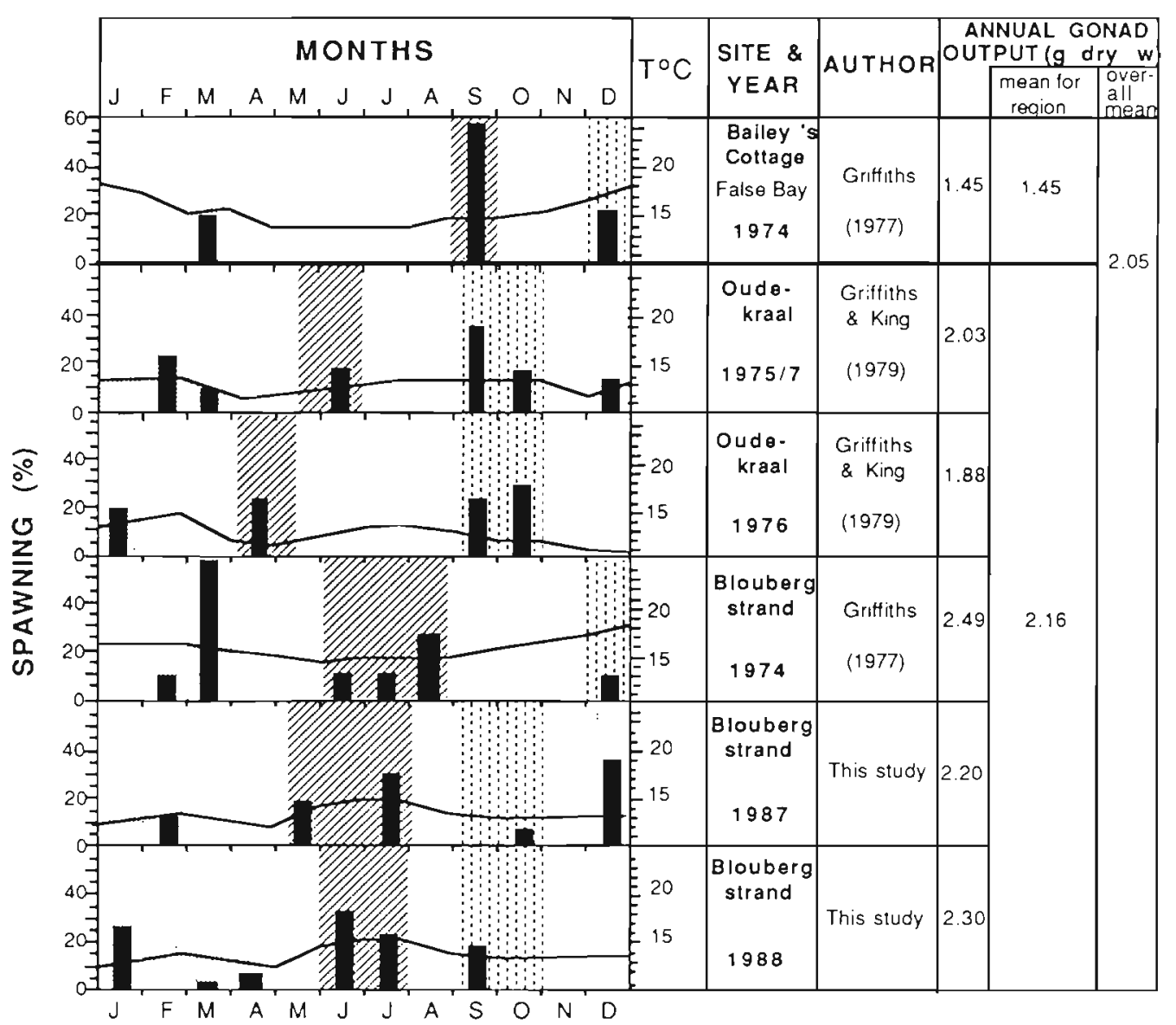

Fig. 4. Aulacomya ater. Synopsis of known records of reproductive seasonality and output. Each horizontal block represents 1 yr of observation. Weight loss as a result of spawning in each month is indicated by a histogram bar, scaled as a percentage of annual reproductive output. These bars are grouped into 'spawning seasons' by shaded areas. A typical temperature curve for each site is overlaid. Total annual gonad output for a $65 \mathrm{~mm}$ individual ( $\mathrm{g}$ dry mass $\mathrm{yr}^{-1}$ ) is shown on the right, both for that particular year and site, and as a regional and overall mean. Temperature data have been either extracted from the original papers of Griffiths (1977) and Griffiths \& King (1979), or in the other cases obtained from Dr. J. Bolton (Botany Department, University of Cape Town, unpubl.)

fairly consistent pattern of 2 major spawnings each year, one in spring/early summer, between September and January, and the second in late autumn, usually between March and June. In Choromytilus meridionalis this second event may comprise a single protracted event, or a series of partial spawnings extending well into winter.

A number of other data sets, both published and unpublished, provide similar information as to the spawning cycles of these species and can be used to give an indication of interannual and geographical variations in reproductive behaviour. An attempt is made to interpret these patterns in Figs. 4 to 7 . Each horizontal block in these diagrams represents a year of observation in which recorded spawnings are shown as black histogram bars. The height of each bar represents the intensity of the spawning, expressed as a percentage of total gonad output for that year. The shaded areas attempt to link these events into recognizable 'spawning seasons'.

Some manipulation of earlier data sets was necessary in order to derive these diagrams [e.g. conversion of wet to dry weights from Griffiths \& King (1979) and from adductor muscle weight to shell length from Griffiths (1977)] and our interpretations of spawning events may slightly differ from those of the original authors. Adopting this technique should nevertheless result in an unbiased, standardised interpretation of condition indices from different sources.

Data sets for each species in the diagrams are arranged vertically from east to west in order to identify geographical gradients in reproductive seasonality. For the 3 essentially west-coast species records are only available from sites in the southwestern Cape, but for Perna perna a far wider geographical range from Durban to Cape Town has been covered. 


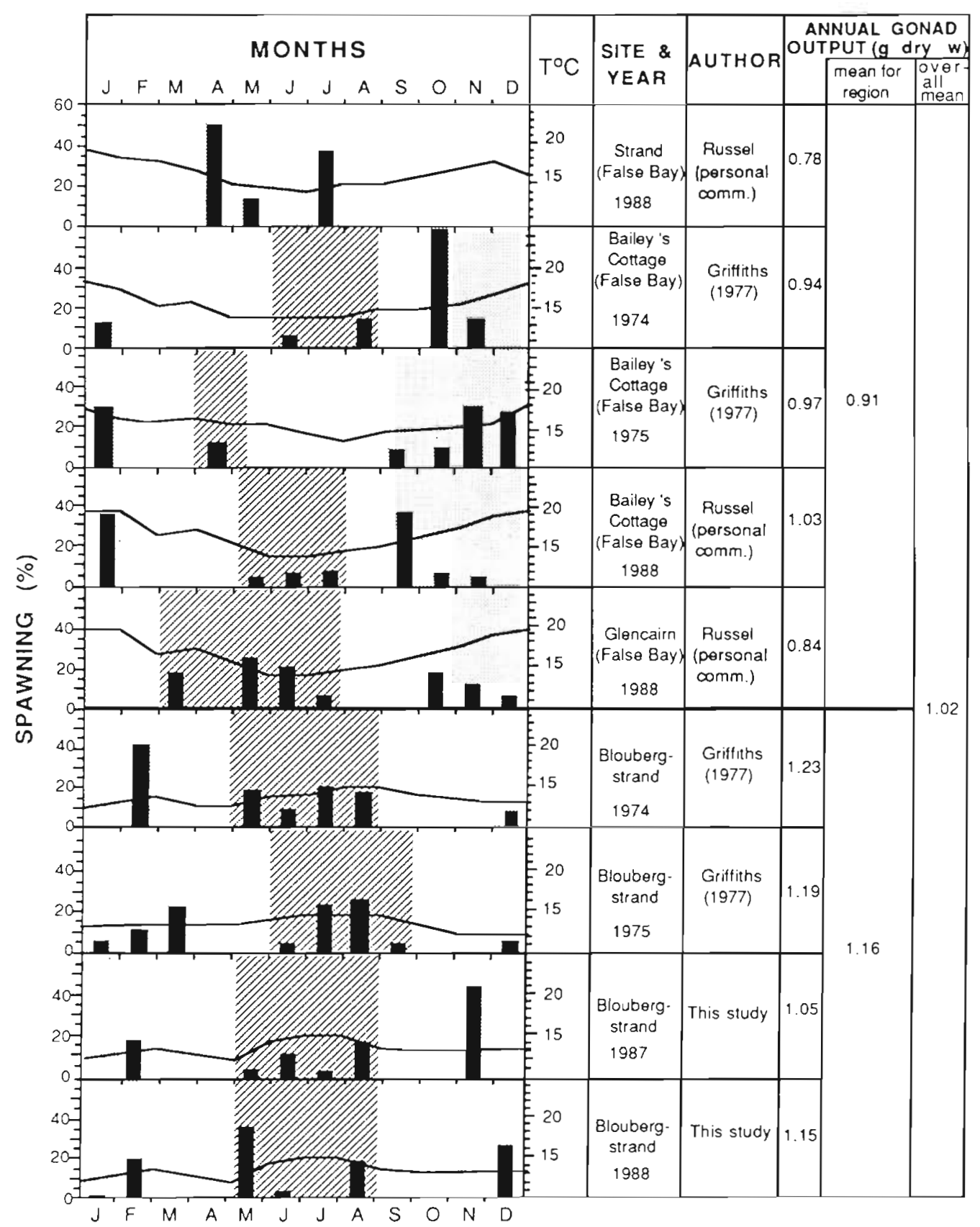

Fig. 5. Choromytilus meridionalis. Synopsis of known records of reproductive seasonality and output (see legend to Fig. 4 for explanation)

For Aulacomya ater 6 sets of observations are available, one from False Bay and the others from along the west coast, on or adjacent to the Cape Peninsula. The records from the west coast all show relatively similar patterns (Fig. 4), with 3 spawnings each year, usually from December to February/March, April to July/ August, and September to October (December in the case of Bloubergstrand in 1974). These events show a high degree of variability in terms of relative intensity.
The False Bay population (Fig. 4, top panel) also spawned 3 times during the year, but these events appear more intense and isolated than in the west coast populations.

The reproductive cycles of Choromytilus meridionalis have been monitored 5 times in False Bay and over $4 \mathrm{yr}$ in Bloubergstrand on the Cape southwest coast. With the one exception in the Strand (False Bay) in 1988, where a single spawning was observed, all the 


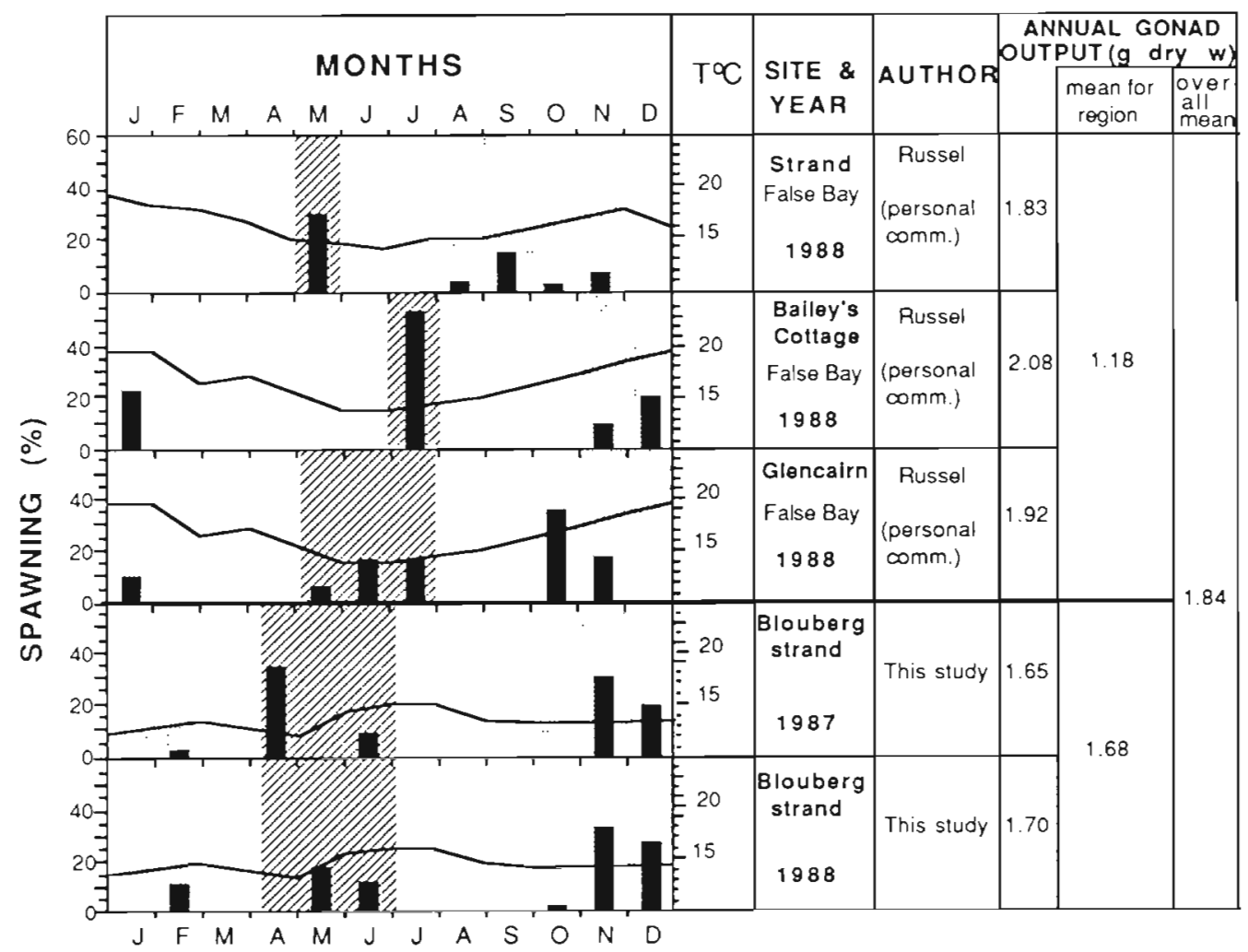

Fig. 6. Mytilus galloprovincialis. Synopsis of known records of reproductive seasonality and output (see legend to Fig. 4 for explanation

records show 2 protracted breeding seasons each year (Fig. 5). In False Bay these are very variable in their timing, but at Bloubergstrand a consistent pattern is evident, with one extended spawning occurring during summer (November to February/March) and the other in mid winter (May to August/ September).

For Mytilus galloprovincialis 3 time-series are available from sites in False Bay and 2 from Bloubergstrand (Fig. 6). All the populations spawned over 2 usually extended periods, with 4 of the 5 populations doing so once in summer (October to February) and again in winter (April/May to July). Again there was an exception in the Strand site in False Bay, where the spawning seasons were displaced to May and to August-November

A large number of records of the breeding seasons of Perna perna are available and are summarized in Fig. 7. In Natal, Berry (1978) reported that most populations spawned in 2 conspicuous peaks between May and October (sometimes prolonged until December), the first event being the largest. However, since some activity occured in each month, we have interpreted this as a single prolonged spawning season (Fig. 7). In Transkei, Lasiak (1986) reports an extended breeding season from April to September, with minor events from December to February. In False Bay a rather variable pattern is evident with a brief but intense winter spawning that can occur between April and August, accompanied by either 1 extended or 2 discrete spring or summer events.

\section{Settlement patterns}

A further index of reproductive activity can be obtained from seasonal records of spat settlement. These were not monitored during the present study, but are available from other southern African authors.

Several years of settlement data for Perna perna are provided by Berry (1978). These suggest that major settlements usually occur over the period from May to August, with a secondary peak in September-October. During 1976, however, this second settlement was the dominant one and resulted in a massive expansion of mussel cover over much of the Natal coast. Less detailed records for a site on the southern Cape coast are provided by Crawford \& Bower (1983). These suggest that secondary settlements occur primarily over summer and early autumn (November to April).

For Choromytilus meridionalis from Saldanha Bay (some $100 \mathrm{~km}$ north of Cape Town), du Plessis (1977) records a broad peak in settlement over the period 


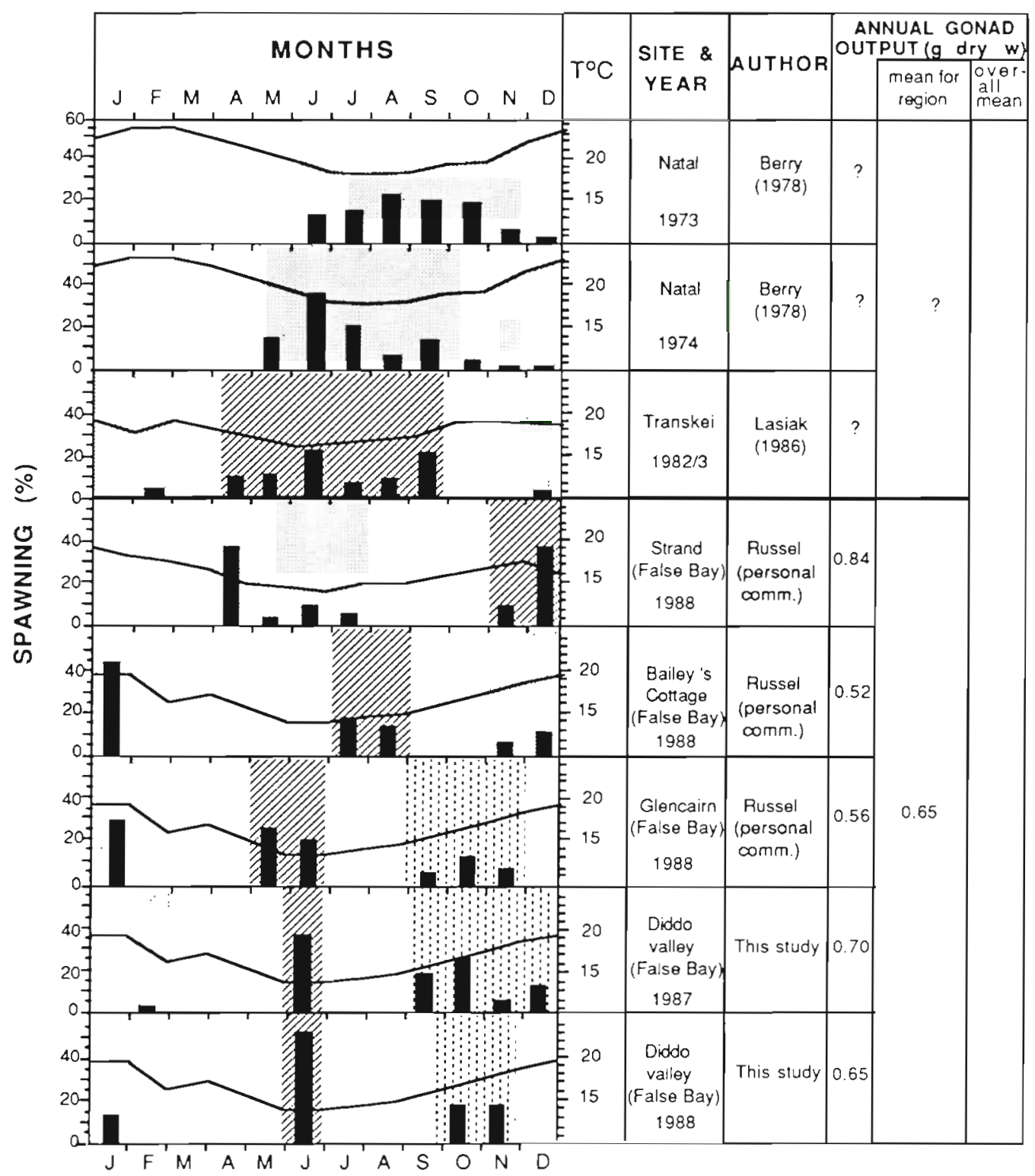

Fig. 7 Perna perna. Synopsis of known records of reproductive seasonality and output (see legend to Fig. 4 for explanation)

October to early May, especially in October-December of each year. In some years this was supplemented by a further peak in March-April, or on one occasion in June-July. Similar findings are reported by Barkai \& Branch (1988) from the same area. They report settlement of $C$. meridionalis on sublittoral plates throughout the period September to June, but with highest recruitments from March to June. Griffiths (1981a) reports a much more irregular pattern for her study site in False Bay, which experienced a dense settlement in December 1974 that was not repeated until August 1978

There are no published data on the recruitment patterns of Aulacomya ater or Mytilus galloprovincialis in
South Africa. Unpublished size-frequency analyses undertaken by Griffiths \& King (1979), however, do show a strong settlement of $A$. ater occurring in September 1975 over a limited area. Similar patchy, intermittent settlement is noted by Pollock (1979), as might be expected from the irregular reproductive cycle of this species. In the case of $M$. galloprovincialis, in Saldanha Bay spat settle on mussel culture ropes mainly over the summer/autumn period, particularly in April (Atlas Sea Farms pers. comm.). Only one author (du Plessis 1977) also measured the duration of larval life. For Choromytilus meridionalis this is reported to range from 31 to $60 \mathrm{~d}$, with a peak of settlement between 35 and $50 \mathrm{~d}$ (mean temperature $15^{\circ} \mathrm{C}$ ). These 
estimates are somewhat longer than most field measurements for other species. Mytilus edulis larvae, for example, have an average lifespan of 3 to $5 \mathrm{wk}$ (Bayne 1976, Kautsky 1982). Duration of larval life is, however, very variable between species (see review by Sastry 1979) and is strongly influenced by a number of factors, particularly temperature and food ration (Bayne 1976). Moreover, pediveliger larvae (at least in $M$. edulis) are known to be able to delay metamorphosis by as much as $40 \mathrm{~d}$ at $10^{\circ} \mathrm{C}$ or $2 \mathrm{~d}$ at $20^{\circ} \mathrm{C}$ if they are unable to find a suitable substratum on which to settle (Bayne 1975).

Given this larval duration there appears to be little correlation between the settlement patterns reported above and the presumed spawning events shown in Figs. 4 to 7 . This may be a reflection of large local and interannual variations in reproductive cycles, and even more so of high and variable dispersal and mortality during the larval stage. This is exemplified by the successive failures of Choromytilus meridionalis re- cruitment at specific sites in False Bay from 1974 to 1978, a period over much of which reproductive output was known to remain consistently high (Griffiths 1981a).

\section{Fluctuations in flesh yield}

From the fluctuation in flesh mass plotted in Fig. 3 it is apparent that the 4 mussel species all exhibit wide disparities both in the absolute dry flesh mass of standard-size individuals and in the range over which tinese values fluctuate over time. These parameters are of particular importance to the mussel culture industry, since the value of the crop is determined largely by the flesh yield, especially when this is used for canning, or sold out of the shell in processed form.

The range over which flesh mass varies in each of the species is depicted more clearly in Fig. 8. The upper
Fig. 8. Annual ranges of variation in the length to weight relationships of 4 southern African mussel species. The upper curve in each diagram represents the length to dry flesh mass relationship in the month of peak gonad condition (averaged over the 2 yr of measurement shown in Fig. 3), while the lower curve represents the minimum relationship. The shaded area thus represents the range over which flesh weights fluctuate during the reproductive cycle

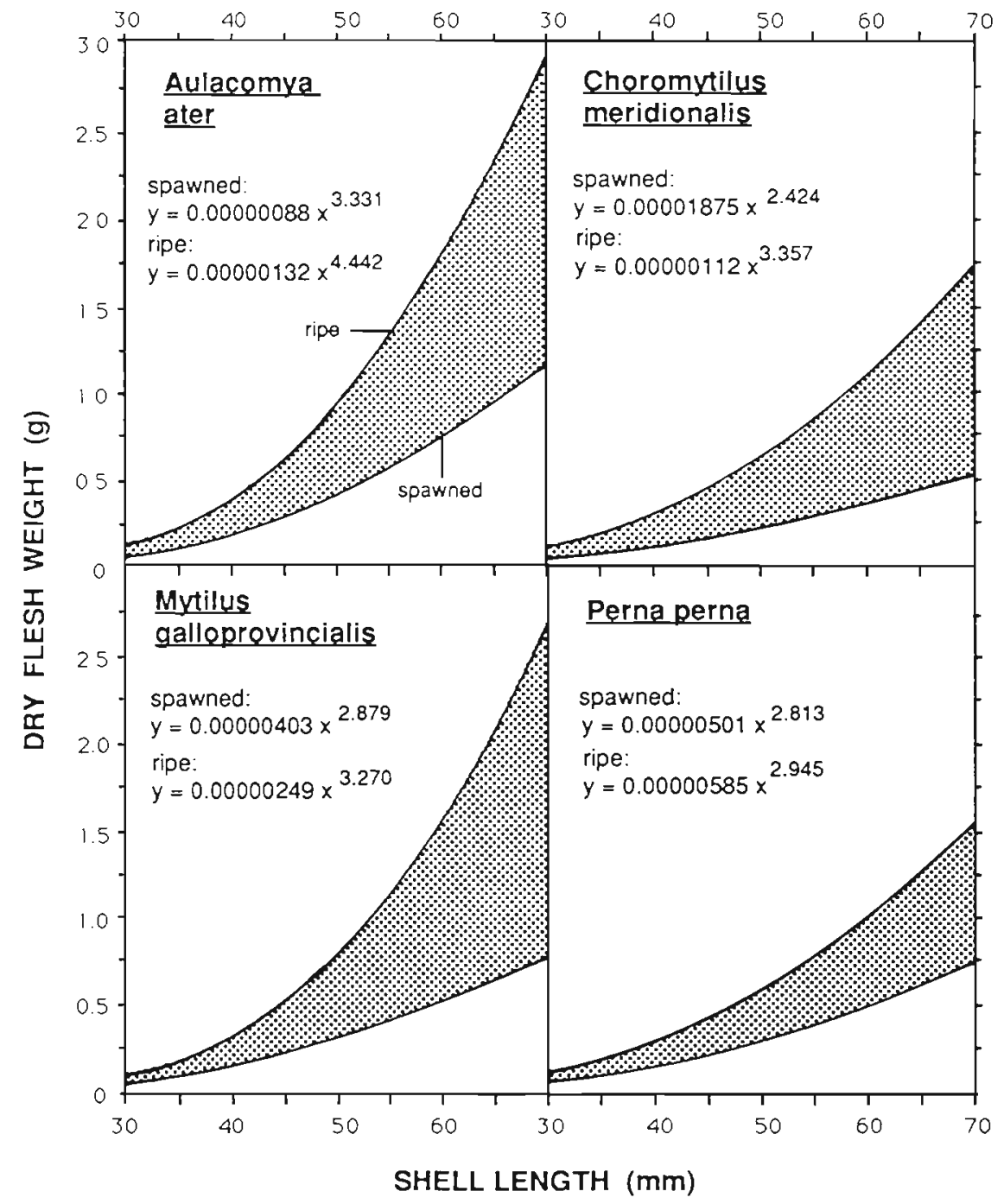


curve in each diagram represents the dry flesh mass to shell length relationship in the month in which flesh mass or condition factor is maximal (averaged over the 2 yr of measurement depicted in Fig. 3), while the lower curve represents the corresponding minimum. The shaded area thus indicates the range over which flesh mass fluctuates during a typical year. Values given in these diagrams may be converted to wet weights by multiplying by 7.1 for Aulacomya ater (Griffiths \& King 1979. Field et al. 1980), by 5.9 for Choromytilus meridionalis (Griffiths 1981a), by 3.7 for Mytilus galloprovincialis (van Erkom Schurink \& Griffiths unpubl.) and by 5.6 for Perna perna (Berry 1978).

Two major features are evident from these plots. Firstly the relationships between shell length and both maximum and minimum dry flesh mass differ markedly between species. Indeed dry flesh mass can vary by almost 2 -fold between individuals of equivalent shell length but of different species. These variations are greatest when the mussels are in a ripe condition. At this point $65 \mathrm{~mm}$ individuals can vary in dry flesh mass from maxima as high as $2.3 \mathrm{~g}$ in Aulacomya ater, through $2.1 \mathrm{~g}$ in Mytilus galloprovincialis, to as little as $1.4 \mathrm{~g}$ and $1.3 \mathrm{~g}$ in Choromytilus meridionalis and Perna perna respectively. After spawning $A$. ater retains the highest body mass $(1.0 \mathrm{~g}$ at $65 \mathrm{~mm})$ followed by $M$. galloprovincialis $(0.7 \mathrm{~g}), \quad P$. perna $(0.6 \mathrm{~g})$ and $C$. meridionalis $(0.5 \mathrm{~g})$. To some extent these variations can be related to the geometry of the shells of the different species, the internal volume of the broader $A$. ater and $M$. galloprovincialis shells being considerably greater than those of the narrow, laterally compressed C. meridionalis and the often elongated, low-shelled $P$. perna (see diagrams in Berry 1978, van Erkom Schurink \& Griffiths 1990).

Secondly, a comparison of the shaded areas in Fig. 8 gives a good indication of the variability in flesh mass and hence capacity of the various species to accumulate and release gonad material within a single spawning cycle. Clearly this is greatest in Mytilus galloprovincialis, in which the accumulation of gonad material can result in a weight increase of 3 -fold over the spawned condition (at $65 \mathrm{~mm}$ ). Equivalent ratios for Choromytilus meridionalis would be 2.8 -fold, for Aulacomya ater 2.3-fold, and for Perna perna 2.2-fold. Put in another way, ripe $65 \mathrm{~mm}$ individuals comprise 57, 64, 67 and 54\% gonad material in $A$. ater, $C$. meridionalis, $M$. galloprovincialis and $P$. perna respectively

Note that, impressive though these figures may be, they almost certainly represent underestimates of the true fluctuations in weight and hence gonad output, since they are based on averages derived from monthly length/weight regressions. Such infrequent samples would miss possible multiple cycles of spawning and gonad buildup with periodicities of less than 1 mo and are also unlikely to capture either the immediate prespawning maximum, or the immediate post-spawning minimum conditions. Moreover, asynchrony between individuals is likely to have resulted in early spawners depressing the 'pre-spawning' estimate and late ones elevating the 'post-spawning' regression curves, thus contracting the true range of body weights experienced by individual mussels.

\section{Reproductive output}

Annual gonad output is a function of both the weight loss in each individual spawning and the frequency of spawnings, which as discussed earlier usually occur 2 or 3 times a year. For the $65 \mathrm{~mm}$ mussels represented in Fig. 3, total annual gamete output may be estimated by summing the declines in dry flesh mass over the year. These total $2.3 \mathrm{~g}$ for an individual $65 \mathrm{~mm}$ Aulacomya ater, $1.7 \mathrm{~g}$ for Mytilus galloprovincialis, $1.1 \mathrm{~g}$ for Choromytilus meridionalis and $0.7 \mathrm{~g}$ for Perna perna, averaged over the years 1987 and 1988

Clearly the larger figure for Aulacomya ater is a function of its 3 annual spawnings, whereas in the remaining forms, which each spawn twice a year, differences result from the volume of gonad material released at each spawning event. The approximate numbers of gametes involved may be gauged from values given by Thompson (1979), who estimated that for Mytilus edulis $1 \mathrm{~g}$ dry gametes was equivalent to some $20 \times 10^{6}$ eggs or $20 \times 10^{10}$ sperm. Since packing densities of mussel beds can exceed 1000 ind. $\mathrm{m}^{-2}$ at a length of $65 \mathrm{~mm}$ (Griffiths \& Hockey 1987), the total number of gametes released by mussel beds is clearly formidable, being of the order of $10^{9}$ eggs or $10^{13}$ sperm $\mathrm{m}^{-2} \mathrm{yr}^{-1}$.

In energetic terms releases of gametic material of this magnitude may have a profound effect on the entire economy of the shore. An attempt to assess this impact more accurately is made in Table 1 , in which we compare reproductive output in typical intertidal populations of our 4 study species. Mussel standing stocks at these sites were derived from field surveys (van Erkom Schurink \& Griffiths 1990). Reproductive outputs were then calculated on the assumption that these populations consist of $65 \mathrm{~mm}$ individuals, as follows. First the whole wet mass of a $65 \mathrm{~mm}$ individual of each species was calculated, using the regression equations given in the legend to Table 1 This figure was then divided into the standing stock to give an estimate of density. Population reproductive output was obtained by multiplying individual reproductive output, given above, by the density and the wet-to-dry conversion ratios (given above) to obtain wet equivalents of reproductive output 
Table 1 Estimated reproductive output (Pr) of representative populations of each of 4 southern African mussel species. Standing stocks were extracted from van Erkom Schurink \& Griffiths (1991) and converted to an equivalent in $65 \mathrm{~mm}$ mussels using the following relationships of total wet weight ( $y$-axis, expressed in $\mathrm{g}$ ) to shell length ( $x$-axis, expressed in mm): Aulacomya ater: $y=$ $0.00005152 x^{3.259}$; Choromytilus meridionalis: $y=0.00020137 x^{2.801} ;$ Mytilus galloprovincialis: $y=0.00012106 x^{2.997}$; Perna perna: $y$ $=0.00024210 x^{2.796}$. Pr/B: ratio of reproductive output to biomass

\begin{tabular}{|c|c|c|c|c|c|}
\hline Species & Site & $\begin{array}{l}\text { Standing stock } \\
\left(\mathrm{kg} \text { wet mass } \mathrm{m}^{-2}\right)\end{array}$ & $\frac{\operatorname{Pr}}{\left(\mathrm{kg} \text { wet mass } \mathrm{m}^{-2} \mathrm{yr}^{-1}\right)}$ & $\mathrm{kJ} \mathrm{m}^{-2} \mathrm{yr}^{-1}$ & $\begin{array}{l}\mathrm{Pr} / \mathrm{B} \\
(\mathrm{kg})\end{array}$ \\
\hline A. ater & $\begin{array}{l}\text { False Bay } \\
\text { Bloubergstrand }\end{array}$ & $\begin{array}{l}20 \\
28\end{array}$ & $\begin{array}{r}5.0 \\
10.4\end{array}$ & $\begin{array}{l}14547 \\
30340\end{array}$ & 0.31 \\
\hline C. meridionalis & $\begin{array}{l}\text { False Bay } \\
\text { Bloubergstrand }\end{array}$ & $\begin{array}{l}19 \\
33\end{array}$ & $\begin{array}{l}4.2 \\
9.2\end{array}$ & $\begin{array}{l}13600 \\
29881\end{array}$ & 0.25 \\
\hline M. galloprovincialis & $\begin{array}{l}\text { False Bay } \\
\text { Bloubergstrand }\end{array}$ & $\begin{array}{l}26 \\
46\end{array}$ & $\begin{array}{l}3.4 \\
8.7\end{array}$ & $\begin{array}{l}18753 \\
47903\end{array}$ & 0.16 \\
\hline P. perna & False Bay & 48 & 6.2 & 22421 & 0.13 \\
\hline
\end{tabular}

per $\mathrm{m}^{2}$. The energy values of reproductive output are also given, based on the calorific values in Fig. 2, converted to wet weight equivalent and weighted according to the sex ratios given in the same figure.

Clearly these values are only approximations, since each population in fact consists of a size range of individuals, the larger of which will contribute greater reproductive output than assumed here, and the smaller ones less. It is nevertheless apparent that secondary production in the form of mussel gametes can be very significant, varying from 3.4 to $10.4 \mathrm{~kg} \mathrm{~m}^{-2} \mathrm{yr}^{-1}$ in the populations listed.

This secondary production can be compared to an estimated total seaweed production of ca $1100 \mathrm{~g} \mathrm{C} \mathrm{m}^{-2}$ $\mathrm{yr}^{-1}$ [ca $23 \mathrm{~kg}$ wet mass, according to the conversion given by Newell et al. (1982)] on an exposed South African rocky shore, as quoted by Branch \& Griffiths (1988), or $17.5 \mathrm{~kg}$ wet mass $\mathrm{m}^{-2} \mathrm{yr}^{-1}$ total seaweed production for a productive kelp bed on the Cape Peninsula (Newell et al. 1982).

Acknowledgements. We are indebted to Grant Russel of the Fishing Industry Research Institute for allowing us access to his unpublished data on annual variations in condition index in False Bay mussel populations, and to Diane Gianakouras for assistance with bomb calorimetry. Financial support was provided through an F.R.D. Core Programme Grant made to G. M. Branch, J. G. Field and C. L. Griffiths. Our thanks to Prof. G. M. Branch and Dr. V. Stuart for their constructive comments on earlier drafts of this manuscript.

\section{LITERATURE CITED}

Adachi, Y, (1972). On the organic matter and the energy value in a mussel, Mytilus galloprovincialis. Graduation thesis, Mukogawa Univ., Japan

Barkai, A., Branch, G. M. (1988). Energy requirements for a dense population of rock lobsters Jasus lalandii: novel importance of unorthodox food sources. Mar. Ecol. Prog. Ser. 50: 83-96
Bayne, B. L. (1975). Reproduction in bivalve molluscs under environmental stress. In: Vernberg, J. F. (ed.) Physiological ecology of estuarine organisms. University of South Carolina Press, Columbia, p. 259-277

Bayne, B. L. (1976). The biology of mussel larvae. In: Bayne, B. L. (ed.) Marine mussels: their ecology and physiology Cambridge University Press, Cambridge, p. 81-120

Bayne, B. L., Worrall, C. M. (1980). Growth and production of mussels Mytilus edulis from two populations. Mar. Ecol. Prog. Ser. 3: 317-328

Berry, P. F. (1978). Reproduction, growth and production in the mussel Perna perna (L), on the east coast of South Africa. Investl Rep. oceanogr. Res. Inst., Durban 48: 1-28

Branch, G. M., Griffiths, C. L. (1988). The Benguela ecosystem, part $V$ The coastal zone. Oceanogr, mar. Biol. A. Rev. 26: 395-486

Chipperfield, P. N. J. (1953). Observations on the breeding and settlement of Mytilus edulis ( $\mathrm{L}$ ) in British waters. J. mar biol. Ass. U.K. 32: 449-476

Crawford, R. J. M., Bower, D. F. (1983). Aspects of growth, recruitment and conservation of the brown mussel Perna perna along the Tsitsikamma coast. Koedoe 26: 123-133

du Plessis, A. J. (1977). Larval development, settlement and growth of the black mussel Choromytilus meridionalis in the Saldanha Bay region. Trans. R. Soc. S. Afr. 42: 303-316

Field, J. G., Griffiths, C. L., Griffiths, R. J., Jarman, N., Zoutendyk, P., Velimirov, B., Bowes, A. (1980). Variation in structure and biomass of kelp communities along the west Cape coast. Trans. R. Soc. S. Afr. 44: 145-203

Fretter, V., Graham, A. (1964). Reproduction. In: Wilbur, K. M., Yonge, C. M. (eds). Physiology of Mollusca. Academic Press, New York, p. 127-164

Griffiths, R. J. (1977). Reproductive cycles in littoral populations of Choromytilus meridionalis $(\mathrm{Kr})$ and Aulacomya ater (Molina) with a quantitative assessment of gamete production in the former, J. exp. Mar. Biol. Ecol. 30: 53-71

Griffiths, R. J. (1981a). Population dynamics and growth of the bivalve Choromvtilus meridionalis ( $\mathrm{Kr}$.) at different tidal levels. Estuar, coast. Shelf Sci. 12: 101-118

Griffiths, R. J. (1981b). Production and energy flow in relation to age and shore level in the bivalve Choromytilus meridionalis ( $\mathrm{Kr}$.). Estuar coast. Shelf Sci. 13: 477-493

Griffiths, C. L., Griffiths, R. J. (1987). Bivalvia. In: Pandian, T. J., Vernberg, F. J. (eds). Animal energetics. Academic Press, New York, p. 1-88

Griffiths, C. L., Hockey, P. A. R. (1987). A model describing the 
interactive roles of predation, competition and tidal elevation in structuring mussel populations. S. Afr. J. mar. Sci. 5: $547-556$

Griffiths, C. L., King, J. A. (1979). Energy expended on growth and gonad output in the ribbed mussel Aulacomya ater. Mar. Biol. 53: 217-222

Hilbish, T. J. (1986). Growth trajectories of shell and soft tissue in bivalves: seasonal variation in Mytilus edulis L. J. exp. mar. Biol. Ecol. 96: 103-113

Hosomi, A. (1985]. The production, daily production, biomass and turn-over of the mussel Mytilus galloprovincialis. Venus, Jap. J. Malacol. 44: 270-277

Kautsky, N. (1982). Quantitative studies on gonad cycle, fecundity, reproductive output and recruitment in a Baltic Mytilus edulis population. Mar. Biol. 68: 143-160

Lasiak, T. (1986). The reproductive cycles of the intertidal bivalves Crassostrea cucullata (Born, 1778) and Perna perna (Linnaeus, 1758) from the Transkei coast, southern Africa. Veliger 29: 226-230

Lubet, P., Brichon, G., Besnard, J. Y., Zwingelstein, G. (1986). Sexual differences in the composition and metabolism of lipids in the mantle of the mussel Mytilus galloprovincialis Lmk (Mollusca: Bivalvia). Comp. Biochem. Physiol. 84B: 279-285

Newell, R. C., Field, J. G., Griffiths, C. L. (1982). Energy balance and significance of micro-organisms in a kelp bed community. Mar. Ecol. Prog. Ser. 8: 103-113

This article was submitted to the editor
Pollock, D. E. (1979). Predator-prey relationships between the rock lobster Jasus lalandii and the mussel Aulacomya ater at Robben Island on the Cape west coast of Africa. Mar. Biol. 52: 347--356

Sastry, A. N. (1979). Pelecypoda (excl. Ostreidae). In: Giese, A. C., Pearse, J. S. (eds) Reproduction of marine invertebrates, Vol. 5. Academic Press, New York, p. 113-292

Seed, R. (1976). Ecology. In: Bayne, B. L. (ed.) Marine mussels: their ecology and physiology. Cambridge University Press, Cambridge, p. 13-65

Suchanek, T H. (1985). Mussels and their role in structuring rocky shore communities. In: Moore, P. G., Seed, R. (eds.) The ecology of rocky coasts. Columbia University Press, New York, p. 70-96

Sugiura, Y. (1959). Seasonal change in sexual maturity and sexuality of Mytilus edulis L. Bull. Jap. Soc. scient. Fish. 25: $1-7$

Thompson, R. J. (1979). Fecundity and reproductive effort in the blue mussel (Mytilus edulis), the sea urchin (Strongylocentrotus droebachiensis) and the snow crab (Chionoecetes opilio) from populations in Nova Scotia and Newfoundland. J. Fish. Res. Bd Can. 36: 955-964

van Erkom Schurink, C., Griffiths, C. L. (1990). Marine mussels in Southern Africa - their distribution patterns, standing stocks, exploitation and culture. J. Shellfish Res. 9: $75-85$

Manuscript first received: February 5, 1991

Revised version accepted: July 17, 1991 